УДК: 616.728.3-018.3-001.5-089(048.8)

DOI.ORG/10.37647/0132-2486-2020-107-4-51-60

\title{
The Problems of Meniscal Root Tears
}

\author{
Zazirnyi I.M. ${ }^{1}$, Kostrub O. O. ${ }^{2}$, Smigielski R. ${ }^{3}$, Andreev A. ${ }^{4}$ \\ ${ }^{1}$ Clinical Hospital "Feofaniya" of the Agency of State Affairs, Kyiv, Ukraine \\ 2SI "Institute of Traumatology and Orthopedics of NAMS of Ukraine", Kyiv, Ukraine \\ ${ }^{3}$ Mirai Instytut Rebabilitacji, Warszaw, Poland \\ ${ }^{4}$ Orthopedics and Traumatology Department, University Multiprofile Hospital for Active Treatment \\ "Santa Anna", Sofia, Bulgaria
}

\begin{abstract}
Summary. Meniscal root tears are defined as radial tears located within $1 \mathrm{~cm}$ from the meniscal attachment or a bony root avulsion. This injury is biomechanically comparable to a total meniscectomy, leading to compromised hoop stresses resulting in decreased tibiofemoral contact area and increased contact pressures in the involved compartment. These changes are detrimental to the articular cartilage and ultimately lead to the development of early osteoarthritis. Surgical repair is the treatment of choice in patients without significant osteoarthritis (Outerbridge grades 3 or 4). Root repairs have been reported to improve clinical outcomes, decrease meniscal extrusion and slow the onset of degenerative changes. In this article, we describe the anatomy, biomechanics, clinical evaluation, treatment methods, outcomes, and post-operative rehabilitation for posterior meniscal root tears.
\end{abstract}

Key words: lateral meniscus; medial meniscus; meniscus root tear; root repair.

\section{Introduction}

Meniscal root tears are defined as bony or soft tissue root avulsion injuries or radial tears within $1 \mathrm{~cm}$ of meniscus root attachment [1-4]. These tears are increasingly being recognized as a cause of morbidity, development of early osteoarthritis (OA), and altered joint kinematics when not surgically repaired [3,5-9]. The prevalence of a complete meniscus root tear in patients with a documented meniscus root tear has been reported to be $9.1 \%$ overall in patients who underwent arthroscopic knee surgery [10]. Moreover, lateral meniscus posterior root tears (LPRT) were 10.3 times more likely to occur with an ACL tear than medial meniscus posterior root tears (MPRT), which were 5.8 times more likely to have concomitant knee chondral defects than LPRTs [11]. Medial meniscus posterior root tears are commonly degenerative and seen in middle aged women and may represent up to $21.5 \%$ of posterior horn medial meniscus tears [11]. Iatrogenic MPRT have also been reported after non-anatomic tibial tunnel placement in posterior cruciated ligament (PCL) reconstrucrion [12]. Injuries to the anterior horns of the menisci are less common and frequently occur iatrogenically, such as during ACL tibial tunnel reaming and tibial nailing on tibial shaft fractures [12-14].

Historically, meniscal root tears were treated with total or partial meniscectomy to achieve short-term benefits. Recent anatomic, biomechanical, and patient reported outcome studies have elucidated this pathology, substan- tiated the necessity of repair, and have led to improved treatment methods. Currently, repair of meniscal root injuries is the treatment of choice with the aim of restoring joint kinematics, contact pressures, and delaying the development of OA $[15,16]$. This review will focus mainly on posterior meniscal root tears including the anatomy, biomechanics, clinical evaluation, treatment methods, outcomes, and post-operative rehabilitation.

\section{Anatomy}

The meniscal roots exhibit main and supplemental fiber attachment sites, which significantly contribute to the native attachment areas and root attachment forces. Therefore, previous anatomic studies need to be interpreted on the basis of whether or not they have included the supplemental fibers [17-21].

\section{Medial Meniscus Posterior Root Attachment (MPRA)}

The MPRA is $9.6 \mathrm{~mm}$ posterior and $0.7 \mathrm{~mm}$ lateral to the medial tibial eminence (MTE), which is the most reproducible osseous landmark [17]. Additionally, the center point of the MPRA can be found $3.5 \mathrm{~mm}$ lateral to the medial cartilage inflection point and $8.2 \mathrm{~mm}$ directly anterior to the most proximal aspect of the PCL tibial attachment point, which represent two other consistent landmarks (Fig. 1) [17].

Lateral Meniscus Posterior Root Attachment (LPRA)

The LPRA is $1.5 \mathrm{~mm}$ posterior and $4.2 \mathrm{~mm}$ medial to the lateral tibial eminence (LTE) [17]. Additionally, the center point of the LPRA is $4.3 \mathrm{~mm}$ medial to the lateral cartilage 
inflection point and $12.7 \mathrm{~mm}$ directly anterior to the most proximal aspect of the PCL tibial attachment [17].

\section{Medial Meniscus Anterior Root Attachment (MARA)}

The MARA inserts along the anterior intercondylar crest of the anterior slope of the tibia [5]. The center of the MARA was reported to be $18.2 \mathrm{~mm}$ anteromedial from the center of the anterior cruciate ligament (ACL) tibial footprint and $27.5 \mathrm{~mm}$ anterolateral from themedial tibial eminence apex (Fig. 2) [17, 22]. The MARA is at risk during intramedullary nailing of tibial fractures [14].

\section{Lateral Meniscus Anterior Root Attachment (LARA)}

LaPrade et al. reported that the area of the LARA averaged $140.7 \mathrm{~mm}^{2}$, given the considerable overlap with the ACL footprint [22]. Furthermore, the LARA site was $5.0 \mathrm{~mm}$ anterolateral from the center of the ACL footprint, $14.4 \mathrm{~mm}$ from the lateral tibial eminence apex and $7.1 \mathrm{~mm}$ from the nearest edge of the lateral articular cartilage. Therefore, the LARA is at high risk for iatrogenic injury during ACL tibial tunnel reaming $[12,17,22]$.

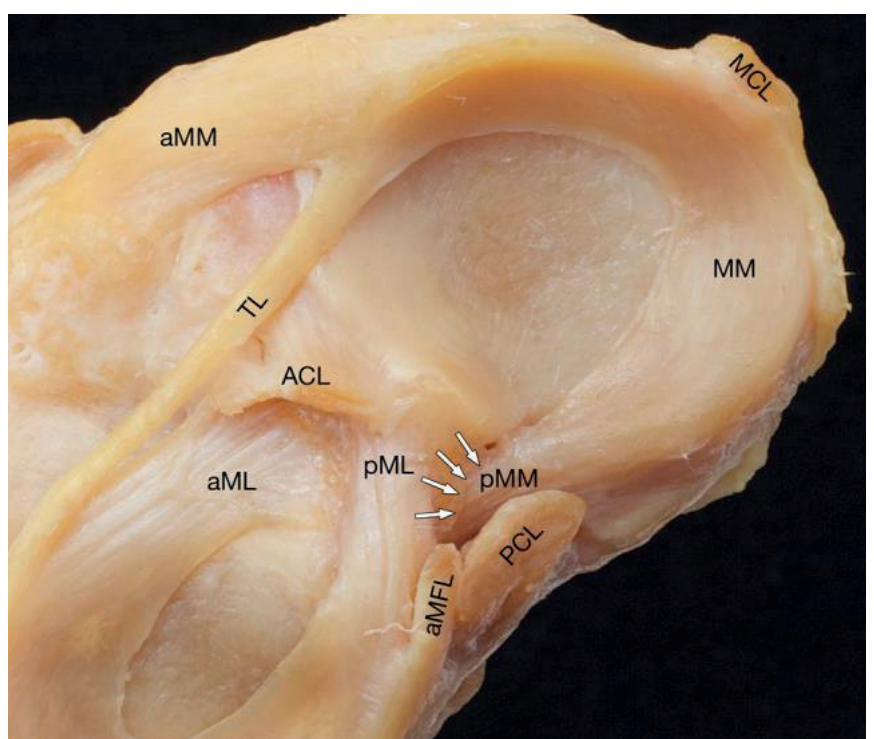

Fig. 1. Anatomical dissection of proximal tibial articular surface (plan view, femur removed). Tibial attachment of posterior root of medial meniscus is marked with white arrows.

$P C L$ - posterior cruciate ligament; $a M F L$ - anterior menisco-femoral ligament (Humphry ligament); $p M L-$ posterior root of lateral meniscus; $A C L$ - anterior cruciate ligament; $a M L$ - anterior root of lateral meniscus; $a M M$ - anterior root of medial meniscus; $p M M$ - posterior root of medial meniscus; $T L$ - transverse ligament (anterior menisco-meniscal ligament), $M C L$ - medial collateral ligament [17]

\section{Biomechanics}

The meniscal roots have an important function for the meniscus to convert axial tibiofemoral loads into hoop stresses [8]. The loss of meniscal anchoring to the tibial plateau results in loss of normal meniscus function, meniscal extrusion, and altered knee kinematics. This leads to unequal and abnormal distribution of knee loading, thereby decreasing tibiofemoral contact area and increasing peak contact pressures [8]. Allaire et al. reported that sectioning of the MPRA resulted in a $25 \%$ increase in medial peak contact pressure when compared to the native state, comparable to that of a total meniscectomy [8]. Similar changes in the loading profile of the knee have been reported for avulsions of the LPRA $[2,9]$. The increased contact pressures due to meniscal root tears are detrimental to the articular cartilage and can lead to the development of early $\mathrm{OA}$ if not treated adequately [23, 24].

In cases of ACL deficiency, the lateral meniscus posterior root plays an important role in stabilizing the knee in both anterior tibial translation (ATT) and during pivoting activities [25]. Therefore, in patients who exhibit a grade 3 Lachman and a 3+ pivot shift, a possible LPRT should be suspected. The LPRA has also been reported to act as the primary stabilizer for internal rotation at higher flexion angles [25]. Based on these biomechanical findings, a repair of a LPRT should be performed concurrently with an ACL reconstruction to avoid persistent instability and increased forces on the ACL graft.

Although speculation still exists on whether or not the shiny white fibers (SWF) and supplemental fibers should be considered as part of the meniscal root attachment, biomechanical investigations have reported that they impact significant contributions to their ultimate failure strengths for the posteromedial, posterolateral and anteromedial roots [19]. Therefore, Ellman et al. suggested that failure to incorporate these fibers during repair might be the reason some surgical techniques do not adequately restore knee biomechanics [19]. Likewise, a non-anatomic repair has been reported to have significant consequences for the long-term health of the tibiofemoral joint $[26,27]$. In porcine and human models, recent studies have reported that a non-anatomic transtibial pullout repair of the medial meniscal roots, anchored only 3-5 mm medial from the native site, substantially increase mean contact pressure and decrease contact area during tibiofemoral loading [26, 27]. Therefore, anatomic repair is necessary to decrease the detrimental factors contributing to the progression of osteoarthritis.

The two-tunnel transtibial pull-out repair technique has become popular among clinicians because of its ability to restore tibiofemoral contact pressures and contact area at time zero $[3,8,28-30]$. The transtibial pull-out technique has also been proposed to have the added benefit of enhanced meniscal healing due to the biological effect provided by tunnel drilling allowing the egression of growth factors and progenitor cells from bone marrow [31]. However, micromotion of the meniscal root, 


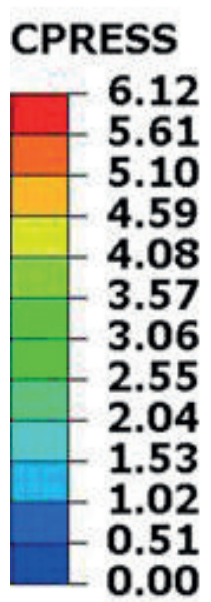

a

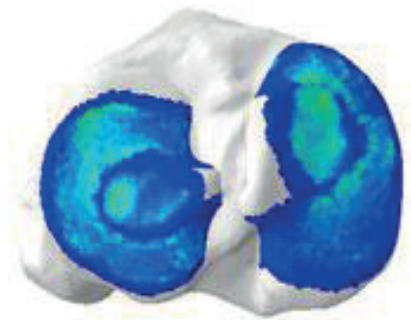

C

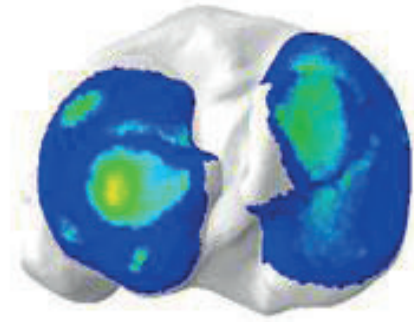

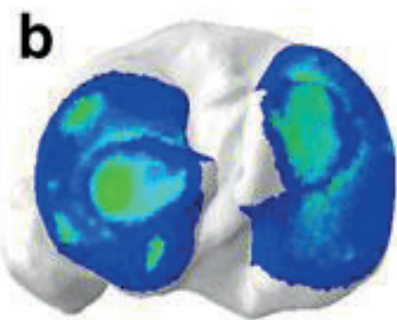

d

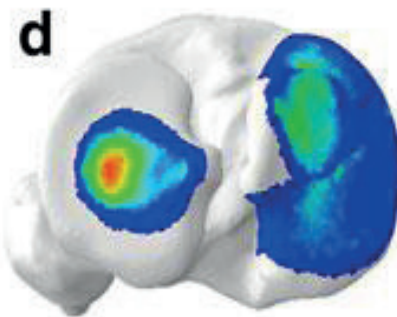

Fig. 2. Time- 0 results of contact pressure distribution (in $\mathrm{MPa}$ )

immediately after the knees were subjected to different conditions.

a - Intact knee; $b$ - a complete radial posterior lateral meniscus root tear (PLMRT); c - a complete radial PLMRT combined with deficiency of posterior menisco-femoral ligament (PMFL); $\mathrm{d}$ - total meniscectomy of lateral meniscus [2]

or "bungee effect" as described by Feucht et al. [2014], caused by long length suture construct, has been an area of concern, but Cerminara et al. reported that the main cause of root displacement was the meniscus-suture interface failure, rather than a "bungee effect" $[28,31]$.

\section{Diagnosis. Clinical Evaluation}

Meniscal root tears can occur during traumatic events, but most cases (around 70\% of MPRT) occur in degenerative knees without a specific injury event or following minor traumatic movement, such as squatting [32,33]. The MPRA is the least mobile of the meniscal roots and, consequently, has a highest incidence of tears. The incidence of MPRT reportedly varies from $10-21 \%$ of medial meniscus tears [34-38]. In the setting of a multiligament injury, the incidence of MPRT is reported to be around $3 \%[6,33$, $39,40]$. Additionally, $80 \%$ of patients with spontaneous osteonecrosis of the knee (SONK), typically involving the medial femoral condyle, have an associated MPRT, which argues against the «spontaneous" etiology of this overload syndrome [41].

The risk factors for MPRT are varus alignment, increased age, high body mass index, and female sex [35-37, 42].

Most meniscus root tears have no history of inciting trauma; therefore, a high degree of suspicion is required in the presence of risk factors. Patients can report joint line pain, but meniscal mechanical symptoms (locking, catching and giving way] are not common [43]. A popping sound can be heard when the patient performs light activities like rising from a chair or squatting [44]. The onset of pain may be subtle and severe with a minor or no evident trauma [45]. The most common findings on physical examination are pain with full knee flexion (66.7\%), joint line tenderness (61.9\%), and a positive Mc-
Murray test (57.1\%) [45]. A MPRT can result in an extruded meniscus palpable along the anteromedial joint line when a varus stress is applied to the knee in full extension. This extrusion disappears when normal knee alignment is restored [46].

\section{Imaging}

Magnetic resonance imaging [MRI] is the imaging modality of choice to diagnose meniscal root tears and concomitant pathologies [32, 35, 49-51]. In a recent prospective level II study, LaPrade and Ho reported a diagnostic sensitivity of $77 \%$, a specificity of $73 \%$, a positive predictive value (PPV) of $22 \%$, and a negative predictive value (NPV) of 97\% using 3.0 T MRI, with a higher sensitivity for MPRT [10] . To assess for a meniscal root injury, T2-weighted sequences are typically utilized with coronal, sagittal, and axial images [49, 52]. Three main signs should be evaluated on MRI when a MPRT is suspected: 1) linear high signal intensity perpendicular to the meniscus (radial tear) at the meniscal root in the axial plane; 2) a vertical linear defect on the meniscal root (truncation sign), which is associated with medial meniscal extrusion $>3 \mathrm{~mm}$; and 3 ) the ghost sign, which is absent in normal meniscus signal in the sagittal plane (Fig. 3) [50]. These three signs when used together have been reported to have a high sensitivity and specificity [10]. Moreover, near perfect intra- and interobserver reliability were reported for MPRT diagnosis on axial, coronal, and sagittal MRI planes [50].

Extrusions of greater than $3 \mathrm{~mm}$ on mid-coronal imaging are significantly associated with articular cartilage degeneration, severe meniscal degeneration, and meniscal root tears (Fig. 4) [53, 54]. Ipsilateral tibiofemoral compartment bone marrow edema and insufficiency fractures are commonly noted in the presence of posterior meniscal tears [32]. 


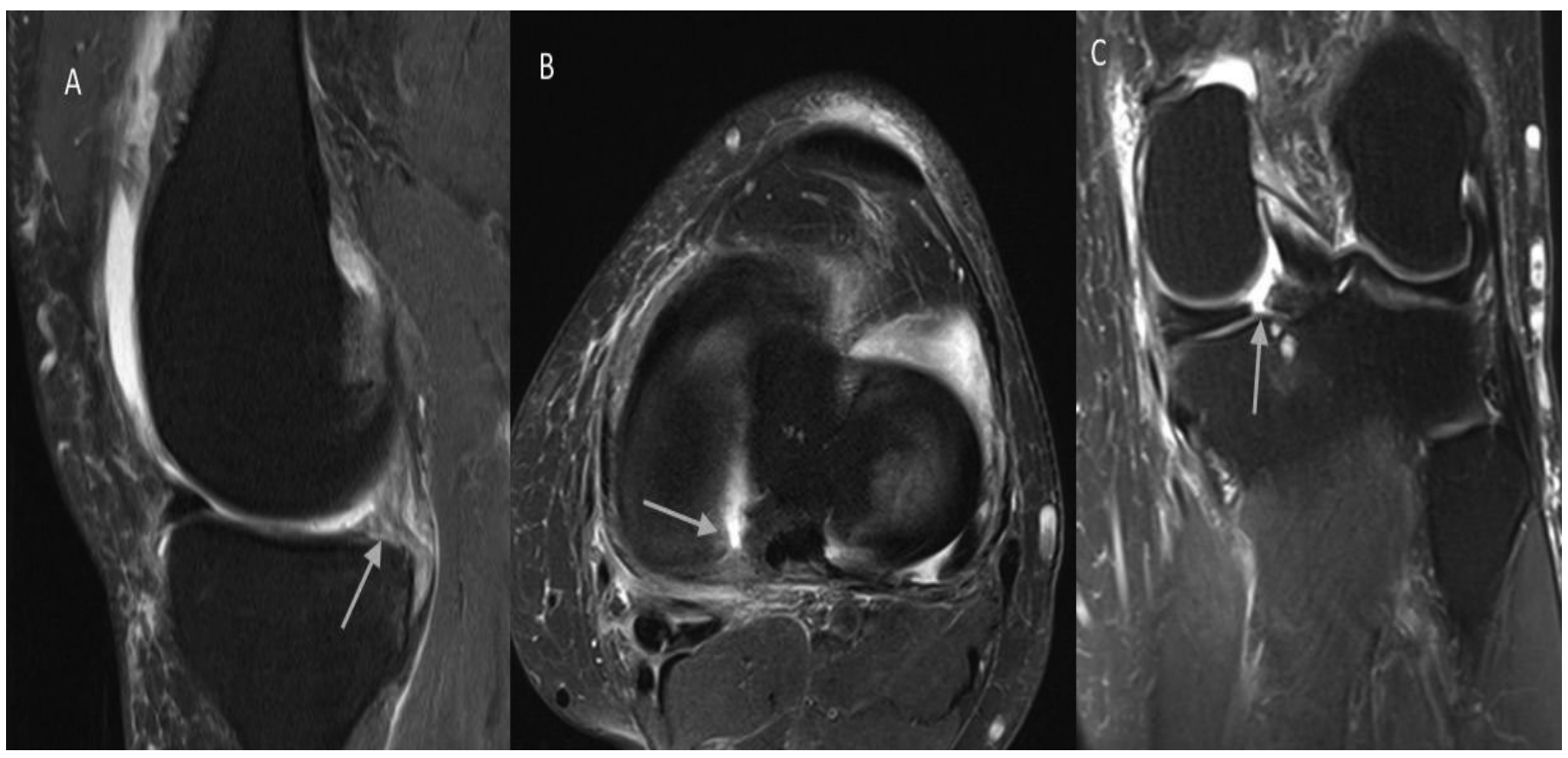

Fig. 3. Left knee MRI showing a medial meniscus posterior root tear (MPRT) (yellow arrow). A - Sagittal plane view. Ghost sign; B - axial plane view; C - coronal plane view [50]

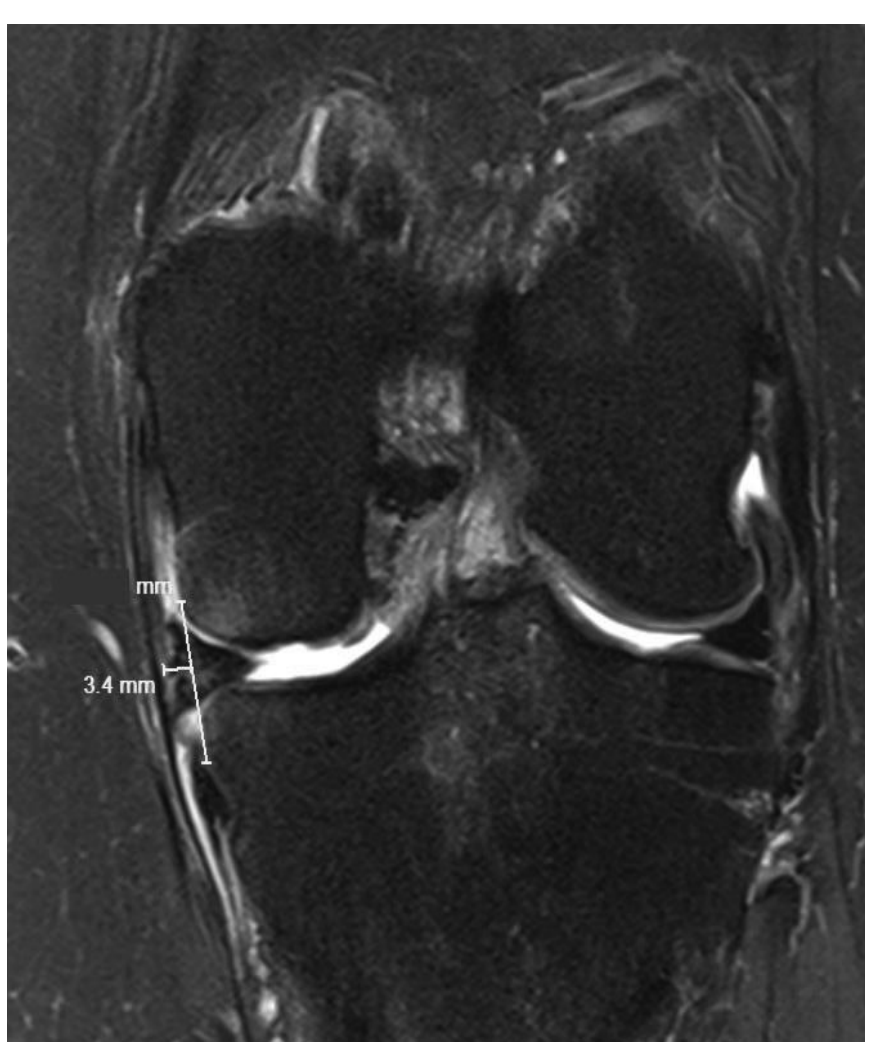

Fig. 4. Left knee MRI showing a medial meniscus extrusion on the coronal plane views [53]

\section{Classifications}

LaPrade et al. (2015) classified posterior root tears according to morphology based on an arthroscopic assessment. Type $1(7 \%)$ is a partial and stable root tear; type 2 $(68 \%)$ is a complete radial tear within $9 \mathrm{~mm}$ of the root attachment. Type 2 tear can be subclassified in $2 \mathrm{a}(38 \%)$, within 0 to $<3 \mathrm{~mm}$; $2 \mathrm{~b}(17 \%)$, between 3 and $<6 \mathrm{~mm}$; and 2c (12\%), between 6 and $9 \mathrm{~mm}$ from the root attachment. Type $3(6 \%)$ is a bucket-handle tear with complete root detachment, type $4(10 \%)$ is a complex oblique or longitudinal tear with complete root detachment, and type 5 is a root bony avulsion (Fig. 5) [47].

Forkel et al. have described another classification for LPRT according to localization and compromise of meniscofemoral ligaments [48]. Type 1 is a real avulsion of the posterior lateral root. This injury can be a result of a trauma or iatrogenic due to a posterior sited ACL tunnel. Type 2 is a radial tear involving only the root and not the meniscofemoral ligament. Type 3 is a radial tear of both root and meniscofemoral ligament.

$\mathrm{J}$-Y Kim et al. classified root tears into 5 types according to the presence of a complete tear and the measured value of the tear gap: type 1 , incomplete root tear; type 2 , complete root tear with no gap or overlap; type 3 , complete root tear with a gap 1-3 mm; type 4, complete root tear with a gap 4-6 mm; and type 5, complete root tear with a gap $7 \mathrm{~mm}[55]$.

\section{Treatment Rationale}

Treatment of meniscal root tears is variable based upon the severity of the injury, timing of injury to surgical intervention, and the condition of the articular cartilage. The goal of surgical repair is to restore joint contact pressures, joint kinematics, and delay the development of OA. Therefore, surgical repair is not indicated for patients with diffuse Outerbridge grades 3-4; however, it may be considered in those with focal chondral deficits to relieve symptoms. The most commonly utilized treatments 


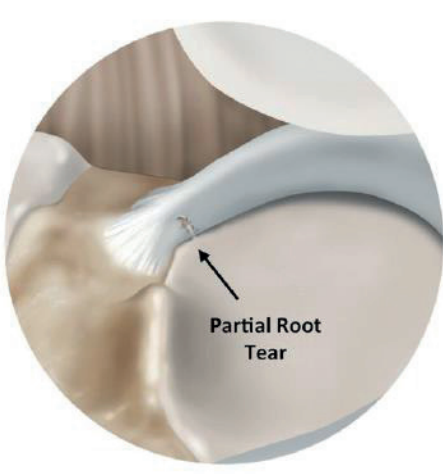

Type I

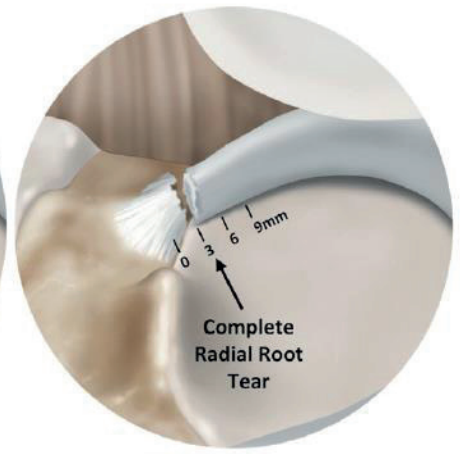

Type 2

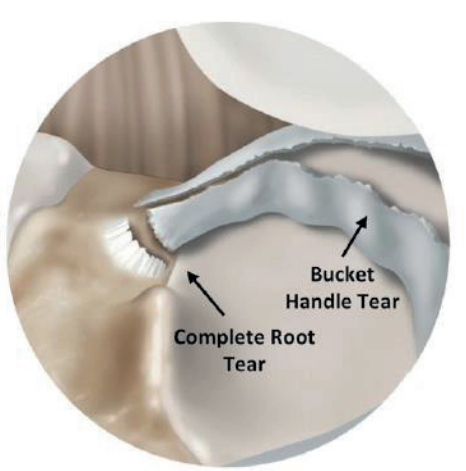

Type 3

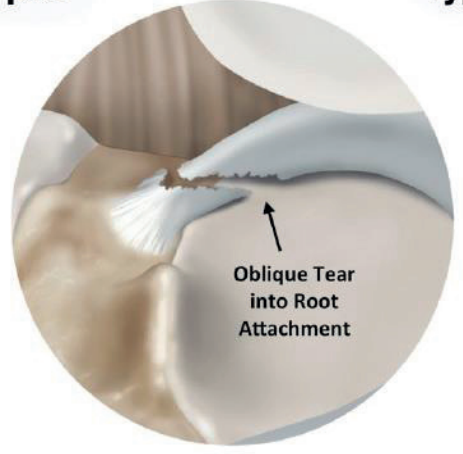

Type 4

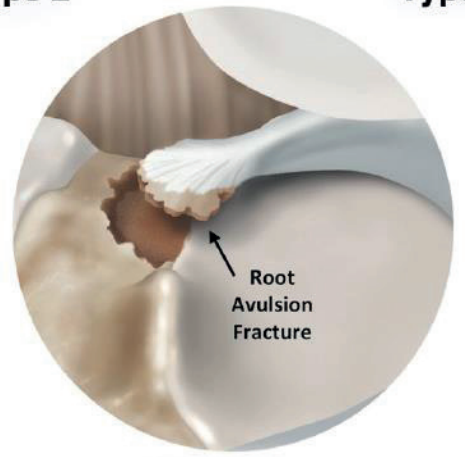

Type 5

Fig. 5. Meniscal root tear classification system illustrated in posterior medial meniscal root. Type 1 - partial stable tear; type 2 - complete radial tear within $9 \mathrm{~mm}$ from attachment; type 3 - bucket-handle tear with complete root detachment; type 4 - complex oblique or longitudinal tear with complete root detachment; type 5 - bony avulsion fracture of the root attachment [47]

for posterior meniscal root tears include non-operative treatment, partial meniscectomy, or repair.

\section{Non-Operative Treatment}

With recent evidence on the importance of the posterior meniscal roots on maintaining hoop stresses, normal knee kinematics and normal contact loading, as well as excellent post-operative patient reported outcomes and established surgical techniques, there are few scenarios not to treat a root tear with a surgical repair. Elderly patients with high grade and diffuse OA (Outerbridge 3-4) are usually candidates for nonoperative treatment. Symptomatic treatment with the use of analgesics (oral or topical), activity modification, and/or an unloader brace can relieve some of the symptoms.

\section{Meniscectomy}

Patients with advanced degenerative changes and persistent mechanical symptoms such as locking and patients who have failed conservative treatment may benefit from a partial or subtotal meniscectomy [42]. However, the development of further OA reliably occurs, making symptom relief often short-lived in contrast to meniscal root surgical repair.

\section{Posterior Meniscal Root Repair}

Anatomic repair of the meniscal root should be attempted whenever possible to prevent meniscus damage and $\mathrm{OA}$, except in cases in which the patient is a poor surgical candidate (significant comorbidities or advanced age), diffuse Outerbridge grade 3 or 4 OA of the ipsilateral compartment, non-symptomatic chronic meniscal root tears, and/or significant limb malalignment unless concurrently corrected $[32,55]$. The two most commonly used repair techniques are suture anchor repair and transtibial meniscal root repair.

\section{Suture Anchor Repair}

Medial meniscal root tears can be treated with suture anchor repair, utilizing one suture anchor with two sutures via an all-inside technique. For a MPRT, an anchor is inserted at the meniscal root anatomic footprint by using a high posteromedial portal. Then, the root is reattached with two vertical sutures [56-58]. This technique is technically demanding and has mainly been reported in patients with grade 3 medial collateral ligament tears.

\section{Transtibial Pull-Out Repair}

Many techniques describing transosseous suture fixation for medial and lateral posterior root tears have been described. The treatment can slightly differ depending on the type of meniscal root tear pattern. This particular technique involves passing sutures through the meniscal root, retrieving them through tunnels drilled in the proximal tibia, and subsequently tying them over a post, button or anterior tibia bone bridge [40, 59-61]. Many meniscal suture configurations have been proposed with different biome- 
chanical properties including two simple stiches, horizontal mattress stitch, modified Mason-Allen (MMA), and two modified loop stiches [62]. However, two simple sutures have been reported to result in the least root displacement, have increased stiffness, and are not significantly different to the more complex (MMA) suture [28, 62]. Single tunnel and double tunnel techniques have been described in attempt to reproduce better the anatomical footprint and enhance biological healing [30]. Fixation with a button is advantageous given that it is less invasive and reduces a risk of soft tissue irritation compared with screw and washer fixation [40].

\section{Outcomes}

\section{Partial meniscectomy vs meniscal root repair}

Partial meniscectomy for MPRT has been reported to significantly improve subjective outcome scores; however, degenerative changes on the Kellgren-Lawrence scale (KL) increased significantly postoperatively at 5 years' follow-up [35, 63]. In a recent retrospective study by Krych et al. comparing a partial medial meniscectomy with nonoperative treatment, no significant difference in final Tegner scores, IKDC, or KL grades, was found between both groups. However, 54\% of the partial medial meniscectomy group progressed to a total knee arthroplasty (TKA) on average in 4.5 years [63].

Meniscal root repairs have been reported to improve subjective patient outcomes. In a recent meta-analysis, Chung et al. reported significant improvements in postoperative clinical scores after surgical repair [23, 24]. Similar results were reported in a recent systematic review by Feucht et al. [64]. Feucht et al. reported an improvement of the Lysholm score [52 to 86] after MPRT repair by arthroscopic transtibial pull-out technique [64]. In a retrospective study comparing transtibial pull-out meniscal root repair to partial meniscectomy with a minimum 5-year follow-up, Chung et al. reported significantly better clinical and radiological outcomes in the repair group [24]. The rate of conversion to a TKA was 34\% in the partial meniscectomy group and none in the root repair group [24]. In a retrospective study, Kim et al. compared partial meniscectomy (28 patients) to meniscal root repair with pull-out technique (30 patients) with a mean follow up of 46 months. Significantly better clinical and radiological results were found in the repair group [65].

LaPrade et al. performed a retrospective Level III study of 50 knees and reported improved subjective outcomes (Lysholm, IKDC, and WOMAC) with posterior meniscal root repairs with an anatomic two-tunnel transtibial pullout technique [66]. There was no significant differences in the failure rate according to age ( $<50 \mathrm{vs}$ $>50$ years) and laterality (MPRT vs LPRT). Patient satisfaction was high with a significant improvement in pain, function, and activity level [66]. Therefore, they suggested that other factors such as OA grade, high BMI, or the ability to comply with the postoperative rehabilitation protocol may be more useful when assessing the appropriate management rather than age as a sole factor $[66,67]$.

\section{Meniscal root repair and arthritis}

In a meta-analysis by Chung et al., it was reported that progression of arthrosis was observed in only $10 \%$ of patients at a mean follow-up of 30.3 months and mean age of 54 years after meniscal root repair [23]. Therefore, it was concluded that a minimum of $79.7 \%$ of patients with MPRT could avoid degenerative changes with surgical repair. In a systematic review by Feucht et al., it was reported that $84 \%$ of patients had no progression of $\mathrm{OA}$ on the Kellgren-Lawrence grading scale after meniscal root repair [64]. These studies suggest that meniscal root repair can slow down the progression of osteoarthritis.

\section{Meniscal root repair and reniscal extrusion}

One of the challenges with meniscal root repair is the presence of meniscal extrusion during follow-up. Chung et al. reported that meniscal extrusion was not reduced in the evaluation of 117 patients of four studies, while Feutch et al. found a $56 \%$ rate of medial meniscal extrusion $[23,64]$. Ki et al. found a decrease in meniscal extrusion in $86.7 \%$ of patients [24]. The biomechanical consequences of extrusion are not fully understood; however, increased joint loading can be expected with increasing meniscus extrusion. Therefore, anatomic reduction and fixation of the meniscus root to the anatomic footprint is important.

\section{Postoperative rehabilitation}

The patient should remain non-weight-bearing for a minimum of 6 weeks following a transtibial pull out meniscal root repair. Passive exercises for a range of motion in a safe flexion zone from $0^{\circ}$ to $90^{\circ}$ begin on the 1-st day after the surgery. After 2 weeks, the patient can be advanced in his knee flexion as tolerated. Gradual progress towards full load begins at 6 weeks. Deep leg presses and squats with knee flexion greater than $70^{\circ}$ should be avoided for at least 4 months after the surgery. Different postoperative rehabilitation protocols have been described in the literature; however, no comparison study has been performed $[32,33,67,68]$.

Although the management of meniscal root tears is evolving and improved subjective outcomes are being observed, no long randomized controlled studies have been published to date. However, with an adequate diagnosis such as a correct clinical and imaging assessment, followed by a correct indication, meniscal root tears should be repaired. This will result in improved clinical and radiological outcomes compared to partial meniscectomy.

Conflict of interest. The authors declare no conflict of interest. This publication has not been, is not and will not be the subject of commercial interest in any form.

\section{References}

1. Choi CJ, Choi YJ, Lee JJ, Choi CH. Magnetic resonance imaging evidence of meniscal extrusion in medial meniscus posterior root tear. Arthroscopy. 2010;26(1):1602-6.DOI: 10.1016/j. arthro.2010.05.004. 
2. BaoHRC, ZhuD, GongH, GuGS. The effect of complete radial lateral meniscus posterior root tear on the knee contact mechanics: a finite element analysis. J Orthop Sci. 2013;18:256-63. DOI: 10.1007/s00776-012-0334-5.

3. Padalecki JR, Jansson KS, Smith SD, Dornan GJ, Pierce CM, Wijdicks CA, et al. Biomechanical consequences of a complete radial tear adjacent to the medial meniscus posterior root attachment site: in situ pull-out repair restores derangement of joint mechanics. Am J Sports Med. 2014;42(3):699-707. DOI: $10.1177 \% 2 \mathrm{~F} 0363546513499314$.

4. Marzo JM, Gurske-DePerio J. Effects of medial meniscus posterior horn avulsion and repair on tibiofemoral contact area and peak contact pressure with clinical implications. Am J Sports Med. 2009;37(I):124-9.DOI: 10.1177\%2F0363546508323254.

5. Koenig JH, Ranawat AS, Umans HR, Difelice GS. Meniscal root tears: diagnosis and treatment. Arthroscopy. 2009;25(9):1025-32.

6. Pagnani MJ, Cooper DE, Warren RF. Extrusion of the medial meniscus. Arthroscopy. 1991;7(3):297-300.

7. Papalia R, Vasta S, Franceschi F, D’Adamio S, Maffulli N, Denaro $\mathrm{V}$. Meniscal root tears: from basic science to ultimate surgery. Br Med Bull. 2013;106(2):91-115.DOI:10.1093/bmb/ldt002.

8. Allaire R, Muriuki M, Gilbertson L, Harner CD. Biomechanical consequences of a tear of the posterior root of the medial meniscus. J Bone Joint Surg Am. 2008;90(9):1922-31.

9. Schillhammer CK, Werner FW, Scuderi MG, Cannizzaro JP. Repair of lateral meniscus posterior horn detachment lesions: a biomechanical evaluation. Am J Sports Med. 2012;40(11):2604-9. DOI: $10.1177 \% 2 \mathrm{~F} 0363546512458574$.

10. LaPrade RF, Ho CP, James E, Crespo B, LaPrade CM, Matheny LM. Diagnostic accuracy of $3.0 \mathrm{~T}$ magnetic resonance imaging for the detection of meniscus posterior root pathology. Knee Surg Sports Traumatol Arthrosc. 2015;23(l):152-7.DOI: 10.1007/s00167-0143395-5.

11. Matheny LM, Ockuly AC, Steadman JR, LaPrade RF. Posterior meniscus root tears: associated pathologies to assist as diagnostic tools. Knee Surg Sports Traumatol Arthrosc. 2015;23(10):3127-31. DOI: 10.1007/s00167-014-3073-7.

12. LaPradeCM,SmithSD, RasmussenMT,HammingMG, WijdicksCA, Engebretsen L, et al. Consequences of tibial tunnel reaming on the meniscal roots during cruciate ligament reconstruction in a cadaveric model, Part 2: The posterior cruciate ligament. Am J Sports Med. 2015;43(1):207-12.DOI: 10.1177\%2F0363546514554769.

13. LaPrade M.D, LaPrade Ch.M, Hamming M.C, Ellman M.B, Turnbull T.L, LaPrade R.F, et al. Intramedullary tibial nailing reduces the attachment area and ultimate load of the anterior medial meniscal root: a potential explanation for anterior knee pain in female patients and smaller patients. Am J Sport Med. 2015;43(7):1670-5. DOI: $10.1177 \% 2 \mathrm{~F} 0363546515580296$.

14. Hoser C, Fink C, Brown C, Reichkendler M, Hackl W, Bartlett J. Long-term results of arthroscopic partial lateral meniscectomy in knees without associated damage. J Bone Joint Surg Br. 2001;83(4):513-6.

15. Stein T, Mehling AP, Welsch F, von Eisenhart-Rothe R, Jager A. Long-term outcome after arthroscopic meniscal repair versus arthroscopic partial meniscectomy for traumatic meniscal tears. Am J Sports Med. 2010;38(8):1542-8.DOI:10.1177\% 2F0363546510364052.

16. SmigielskiR, BeckerR, ZdanowiczU, CiszekB. Medial meniscus anatomy-from basic science to treatment. Knee Surg Sports Traumatol Arthrosc. 2015;23:8-14.DOI:10.1007/s00167-014-3476-5

17. AndersonCJ,ZieglerCG, WijdicksCA,Engebretsen L, LaPradeRF. Arthroscopically pertinent anatomy of the anterolateral and posteromedial bundles of the posterior cruciate ligament. J Bone Joint Surg Am. 2012;94(21):1936-45.DOI: 10.2106 / JBJS.K.01710.
18. Ellman MB, LaPrade CM, Smith SD, Rasmussen MT, Engebretsen L, Wijdicks CA, et al. Structural properties of the meniscal roots. Am J Sports Med. 2014;42(8):1881-7. DOI: $10.1177 \% 2 \mathrm{~F} 0363546514531730$.

19. Kohn D, Moreno B. Meniscus insertion anatomy as a basis for meniscus replacement: a morphological cadaveric study. Arthroscopy. 1995;11(1):96-103.

20. Johnson DL, Swenson TM, Livesay GA, Aizawa H, Fu FH, Harner CD. Insertion-site anatomy of the human menisci: gross, arthroscopic, and topographical anatomy as a basis for meniscal transplantation. Arthroscopy. 1995;11(4):386-94. DOI: 10.1016/0749-8063(95)90188-4.

21. LaPrade CM, Ellman MB, Rasmussen MT, James EW, Wijdicks CA, Engebretsen L, et al. Anatomy of the anterior root attachments of the medial and lateral menisci: a quantitative analysis. Am J Sport Med. 2014;42(10):2386-92.DOI: 10.1177\%2F0363546514544678.

22. Chung KS, Ha JK, Ra HJ, Kim JG. A meta-analysis of clinical and radiographic outcomes of posterior horn medial meniscus root repairs. Knee Surg Sports Traumatol Arthrosc. 2016;24(5):145568.DOI:10.1007/s00167-015-3832-0.

23. Chung KS, Ha JK, Yeom CH, Ra HJ, Jang HS, Choi SH, et al. Comparison of clinical and radiologic results between partial meniscectomy and refixation of medial meniscus posterior root tears: a minimum 5-year follow-up. Arthroscopy. 2015;31(10):1941-50. DOI: 10.1016/j.arthro.2015.03.035.

24. Frank JM, Moatshe G, Brady AW, Dornan GJ, Coggins A, Muckenhirn KJ, et al. Lateral meniscus posterior root and meniscofemoral ligaments as stabilizing structures in the ACL-deficient knee: a biomechanical study. Orthop J Sport Med. 2017;5(6):1-7. DOI: $10.1177 \% 2 \mathrm{~F} 2325967117695756$.

25. LaPrade CM, Foad A, Smith SD, Turnbull TL, Dornan GJ, Engebretsen L, et al. Biomechanical consequences of a nonanatomic posterior medial meniscal root repair. Am J Sport Med. 2015;43(4):912-20.DOI: 10.1177\%2F0363546514566191.

26. Starke C, Kopf S, Grobel KH, Becker R. The effect of a nonanatomic repair of the meniscal horn attachment on meniscal tension: a biomechanical study. Arthroscopy. 2010;26(3):358-65. DOI: 10.1016/j.arthro.2009.08.013.

27. Cerminara AJ, LaPrade CM, Smith SD, Ellman MB, Wijdicks CA, LaPrade RF. Biomechanical evaluation of a transtibial pull-out meniscal root repair: challenging the bungee effect. Am J Sports Med. 2014;42(12):2988-95. DOI: $10.1177 \% 2 \mathrm{~F} 0363546514549447$.

28. Harner CD, Mauro CS, Lesniak BP, Romanowski JR. Biomechanical consequences of a tear of the posterior root of the medial meniscus. Surgical technique. J Bone Joint Surg Am. 2009;91(2):257-70.DOI: 10.2106 / JBJS.I.00500.

29. LaPrade CM, LaPrade MD, Turnbull TL, Wijdicks CA, LaPrade RF. Biomechanical evaluation of the transtibial pull-out technique for posterior medial meniscal root repairs using 1 and 2 transtibial bone tunnels. Am J Sports Med. 2015;43(4):899-904. DOI: $10.1177 \% 2 \mathrm{~F} 0363546514563278$.

30. Feucht MJ, Grande E, Brunhuber J, Rosenstiel N, Burgkart R, Imhoff $\mathrm{AB}$, et al. Biomechanical comparison between suture anchor and transtibial pull-out repair for posterior medial meniscus root tears. Am J Sports Med. 2014;42(l):187-93. DOI: $10.1177 \% 2 \mathrm{~F} 0363546513502946$.

31. Bhatia S, LaPrade CM, Ellman MB, LaPrade RF. Meniscal root tears: significance, diagnosis, and treatment. Am J Sports Med. 2014;42(12):3016-30.DOI: 10.1177\%2F0363546514524162.

32. Kim YJ, Kim JG, Chang SH, Shim JC, Kim SB, Lee MY. Posterior root tear of the medial meniscus in multiple knee ligament injuries. Knee. 2010;17(5):324-8. 
33. Jones AO, Houang MT, Low RS, Wood DG. Medial meniscus posterior root attachment injury and degeneration: MRI findings. Australas Radiol. 2006;50(4):306-13.

34. Ozkoc G, Circi E, Gone U, Irgit K, Pourbagher A, Tandogan RN. Radial tears in the root of the posterior horn of the medial meniscus. Knee Surg Sports Traumatol Arthrosc. 2008;16(9):849-54. DOI:10.1007\%2Fs00167-008-0569-z.

35. Bin SI, Kim JM, Shin SJ. Radial tears of the posterior horn of the medial meniscus. Arthroscopy. 2004;20(4:373-8.

36. Hwang BY, Kim SJ, Lee SW, Lee HE, Lee CK, Hunter DJ, et al. Risk factors for medial meniscus posterior root tear. Am J Sports Med. 2012;40(7):1606-10.

37. Thompson WO, Thaete FL, Fu FH, Dye SF. Tibial meniscal dynamics using three-dimensional reconstruction of magnetic resonance images. Am J Sports Med.1991;19(3):210-5.

38. Brody JM, Lin HM, Hulstyn MJ, Tung GA. Lateral meniscus root tear and meniscus extrusion withMENISCAL ROOTS anterior cruciate ligament tear. Radiology. 2006;239(3):805-10. DOI: 10.1148/radiol.2393050559.

39. Kim YM, Rhee KJ, Lee JK, Hwang DS, Yang JY, Kim SJ. Arthroscopic pullout repair of a complete radial tear of the tibial attachment site of the medial meniscus posterior horn. Arthroscopy. 2006;22(7):795.el-4.

40. Robertson DD, Armfield DR, Towers JD, Irrgang JJ, Maloney WJ, Harner CD. Meniscal root injury and spontaneous osteonecrosis of the knee: an observation. J Bone Joint Surg Br. 2009;91(2):190- 5.DOI:10.1302/0301-620X.91B2.21097.

41. LaPrade RF, Arendt EA, Getgood A, Faucett SC. The menisci. Berlin, Heidelberg: Springer Berlin Heidelberg; 2017.206 p.

42. Lee JH, Lim YJ, Kim KB, Kim KH, Song JH. Arthroscopic pullout suture repair of posterior root tear of the medial meniscus: radiographic and clinical results with a 2 -year follow-up. Arthroscopy. 2009;25(9):951-8

43. Lee DW, Ha JK, Kim JG. Medial meniscus posterior root tear: a comprehensive review. Knee Surg Relat Res. 2014;26(3)125-34. DOI: $10.5792 \% 2 \mathrm{Fksrr} .2014 .26 .3 .125$.

44. Kim JH, Chung JH, Lee DH, Lee YS, Kim JR, Ryu KJ. Arthroscopic suture anchor repair versus pullout suture repair in posterior root tear of the medial meniscus: A prospective comparison study. Arthroscopy. 2011;27(12):1644-53.

45. Seil R, Duck K, Pape D. A clinical sign to detect root avulsions of the posterior horn of the medial meniscus. Knee Sports Surg Traumatol Arthrosc. 2011;19(12):2072-5.

47. LaPrade CM, James EW, Cram TR, Feagin JA, Engebretsen L, LaPrade RF. Meniscal root tears: a classification system based on tear morphology. Am J Sports Med.2015; 43(2):363-9.DOI: 10.1177\%2F0363546514559684.

48. Forkel P, Foehr P, Meyer JC, Herbst E, Petersen W, Brucker PU, et al. Biomechanical and viscoelastic properties of different posterior meniscal root fixation techniques. Knee Surg Sports Traumatol Arthrosc. 2017;25(2):403-10.

49. De Smet AA, Blankenbaker DG, Kijowski R, Graf BK, Shinki $\mathrm{K}$. MR diagnosis of posterior root tears of the lateral meniscus using arthroscopy as the reference standard. AJR Am J Roentgenol. 2009;192(2):480-6.

50. Choi SH, Bae S, Ji SK, Chang MJ. The MRI findings of meniscal root tear of the medial meniscus: emphasis on coronal, sagittal and axial images. Knee Surg Sports Traumatol Arthrosc. 2012;20(10):2098-103.DOI:10.1007\%2 Fs00167-011-1794-4.

51. Lee SY, Jee WH, Kim JM. Radial tear of the medial meniscal root: reliability and accuracy of MRI for diagnosis. AJR Am J Roentgenol. 2008;191(1):81-5.
52. Lerer DB, Umans HR, Hu MX, Jones MH. The role of eniscal root pathology and radial meniscal tear in medial meniscal extrusion. Skeletal Radiol.2004;33(10):569-74.

53. Costa CR, Morrison WB, Carrino JA. Medial meniscus extrusion on knee MRI: is extent associated with severity of degeneration or type of tear? AJR Am J Roentgenol.2004;183(1):17-23. 54. Jae-Young Kim, Seong-Il Bin, Jong-Min Kim, Bum-Sik Lee, Sung-Mok Oh, Won-Joon Cho. A Novel Arthroscopic Classification of Degenerative Medial Meniscus Posterior Root Tears Based on the Tear Gap. The Orthopaedic Journal of Sports Medicine, 2019 Mar; 7(3): 2325967119827945. Published online 2019 Mar 18. DOI: $10.1177 / 2325967119827945$

55. Choi NH, Son KM, Victoroff BN. Arthroscopic allinside repair for a tear of posterior root of the medial meniscus: a technical note. Knee Surg Sports Traumatol Arthrosc.2008; 16(9):891-3.

57. Kim JH, Shin DE, Dan JM, Nam KS, Ahn TK, Lee DH. Arthroscopic suture anchor repair of posterior root attachment injury in medial meniscus: technical note. Arch Orthop Trauma Surg.2009;129(8):1085-8.

58. Jung YH, Choi NH, Oh JS, Victoroff BN. All-Inside repair for a root tear of the medial meniscus using a suture anchor. Am J Sports Med.2012;40(6):1406-11.DOI: 10.1177\%2F0363546512439181.

59. Raustol OA, Poelstra KA, Chhabra A, Diduch DR. The meniscal ossicle revisited: etiology and an arthroscopic technique for treatment. Arthroscopy.2006; 22(6):687.el-3.

60. Ahn JH, Wang JH, Yoo JC, Noh HK, Park JH. A pull out suture for transection of the posterior horn of the medial meniscus: using a posterior trans-septal portal. Knee Surg Sports Traumatol Arthrosc.2007;15(12):1510-3.

61. Nicholas SJ, Golant A, Schachter AK, Lee SJ. A new surgical technique for arthroscopic repair of the meniscus root tear. Knee Surg Sports Traumatol Arthrosc.2009; 17(12):1433-6. DOI:10.1007\%2Fs00167-009-0874-1.

62. Feucht MJ, Grande E, Brunhuber J, Rosenstiel N, Burgkart $\mathrm{R}$, Imhoff $\mathrm{AB}$, et al. Biomechanical evaluation of different suture materials for arthroscopic transtibial pull-out repair of posterior meniscus root tears. Knee Surg Sport Traumatol Arthrosc.2013;23(1):132-9.

63. Krych AJ, Johnson NR, Mohan R, Dahm DL, Levy BA, Stuart J. Partial meniscectomy provides no benefit for symptomatic degenerative medial meniscus posterior root tears. Knee Surg Sports Traumatol Arthrosc.2017;26(4):1117-22.DOI:10.1007/ s00167-017-4454-5.

64. Feucht MJ, Kuhle J, Bode G, Mehl J, Schmal H, Sudkamp NP, et al. Arthroscopic transtibial pullout repair for posterior medial meniscus root tears: a systematic review of clinical, radiographic, and second-look arthroscopic results. Arthroscopy.2015;31(9):1808-16.DOI: 10.1016/j.arthro.2015.03.022.

65. Kim SB, Ha JK, Lee SW, Kim DW, Shim JC, Kim JG, et al. Medial meniscus root tear refixation: Comparison of clinical, radiologic, and arthroscopic findings with medial meniscectomy. Arthroscopy.2011;27(3):346-54.

66. LaPrade RF, Matheny LM, Moulton SG, James EW, Dean CS. Posterior meniscal root repairs: outcomes of an anatomic transtibial pull-out technique. Am J Sports Med.2017;45(4):884-91. DOI: $10.1177 \% 2 \mathrm{~F} 0363546516673996$.

67. Moon HK, Koh YG, Kim YC, Park YS, Jo SB, Kwon SK. Prognostic factors of arthroscopic pull-out repair for a posterior root tear of the medial meniscus. Am J Sports Med. 2012;40(5):113843.DOI: $10.1177 \% 2 \mathrm{~F} 0363546511435622$.

68. Seo HS, LeeSC, Jung KA.Second-look arthroscopic findings after repairs of posterior root tears of the medial meniscus. Am J Sports Med.2011;39(1):99-107.DOI: 10.1177\%2F0363546510382225. 


\section{Проблеми ушкодження кореня меніска}

Зазірний I.M. ${ }^{1}$, Коструб О.О. ${ }^{2}$,Шмігельський ${ }^{3}$, , Андреев A. ${ }^{4}$

${ }^{1}$ Клінічна лікарня “Феофанія" Державного управління справами, м. Київ

'Ду "Інститут травматологіï та ортопедії НАМН України", м. Київ

3нститут мірай, м. Варшава, Польща

${ }^{4}$ Клініка ортопедії та травматологї̈, Університетська багатопрофільна лікарня активного лікування "Святої Анни", м. Софія, Болгарія

Резюме. Ушкодження кореня меніска визначаються як радіальні ушкодження, розташовані на відстані 1 см від місия прикріплення меніска, або відрив кісткового блоку з кріпленням меніска до нъого. Ця травма біомеханічно порівнюється із загальною меніскектомією, що призводить до зменшення площі контакту між великогомілковою та стегновою кістками та збільшення контактного тиску в ураженому відділі. Ці зміни згубно впливають на суглобовий хрям $i$, зрештою, призводять до розвитку раннього артрозу. Хірургічне відновлення - ие лікування, яке обирають для пацієнтів без значного остеоартрозу (3-й або 4-й ступінь за Outerbridge). Повідомлялося, що відновлення коренів меніска покрашує клінічні результати, зменшує екструзію меніска та уповільнюе настання дегенеративних змін. Ми описуємо анатомію, біомеханіку, клінічну оцінку, методи лікування, результати та післяоперащійну реабілітацію при розривах кореня заднього рогу меніска.

ключові слова: латеральний меніск; медіальний меніск; розрив кореня меніска; відновлення кореня меніска.

\section{Проблемы повреждения корня мениска}

Зазирный И.м. ${ }^{1}$, Коструб А.А. ${ }^{2}$,Шмигельский ${ }^{3}{ }^{3}$, Андреев А. ${ }^{4}$

${ }^{1}$ Клиническая больнича "Феофания" Государственного управления делами, г. Киев

"ГУ "Институт травматологии и ортопедии НАМН Украины", г. Киев

${ }^{3}$ Институт Мирай, г. Варшава, Польша

${ }^{4}$ Клиника ортопедии и травматологии, Университетская многопрофильная больница активного лечения “Святой Анны”, г. София, Болгария

Резюме. Разрывы корня мениска определяются как радиальные повреждения, расположенные на расстоянии $1 \mathrm{~cm} \mathrm{от} \mathrm{места} \mathrm{прикрепления} \mathrm{мениска,} \mathrm{или} \mathrm{отрыв}$ костного блока с креплением мениска к нему. Эта травма биомеханически сравнима с тотальной менискэктомией, что приводит к уменьшению площади контакта между большебериовой и бедренной костями и увеличению контактного давления в пораженном отделе. Эти изменения губительны для суставного хряща и, в конечном итоге, приводят к развитию раннего артроза. Хирургическое восстановление - это лечение, которое выбирают для пащиентов без значительного остеоартроза (3-я или 4-я степень по Outerbridge). Сообщалось, что восстановление корней улучшает клинические результаты, снижает экструзию мениска и замедляет наступление дегенеративных изменении. Мы описываем анатомию, биомеханику, клиническую оценку, методы лечения, исходы и послеоперачионную реабилитацию при разрывах корня заднего рога мениска.

Ключевые слова: латеральный мениск; медиальный мениск; разрыв корня мениска; восстановление корня мениска.

\section{Відомості про авторів:}

Зазірний Ігор Михайлович - доктор медичних наук, керівник Центру ортопедї, травматологї $і$ спортивної медицин клінічної лікарні "Феофанія" Державного управління справами, вул. акад. Заболотного, 21, Київ, 03143, Украйна. ORCID: 00000001-7890-1499. 
Коструб Олександр Олексійович - доктор медичних наук, професор, завідувач відділу спортивної та балетної травми ду "Інститут травматології та ортопедї НАМН України", вул. Бульварно-Кудрявська, 27, Київ, 01601, україна. ORCID: 00000001-7925-9362.

Шмігельський Роберт - доктор медичних наук, ортопед в Інституті мірай, вул. Вольська, 96, Варшава, 01-126, Польща. ORCID: 0000-0001-8978-9666.

Андреев Атанас - кандидат медичних наук, лікар клініки ортопедії та травматології, Університетська багатопрофільна лікарня активного лікування "Святої Анни", вул. Димитр Молов, 1, Софія, Болгарія. ORCID: 0000-0002-7957-6787.

\section{Information about autbors:}

Zazirnyi Ibor Mykbailovych - D.Med.Sc., head of the Center of Orthopedics, Traumatology and Sports Medicine of Clinical Hospital "Feofaniya" of the Agency of State Affairs, 21 Zabolotnoho Akademika St., Kyiv, 03143, Ukraine. ORCID: 0000-0001-7890-1499.

Kostrub Olexandr Oleksiiovych - D.Med.Sc., professor, head of the Department of Sports and Ballet Injuries, SI "Institute of Traumatology and Orthopedics of NAMS of Ukraine", 27 Bulvarno-Kudriavska St., Kyiv, 01601, Ukraine. ORCID: 0000-0001-7925-9362.

Robert Smigielski -D.Med.Sc., orthopedist at the Mirai Instytut Rebabilitacji, 96 Wolska St., 01-126, Warszaw, Poland. ORCID: 0000-0001-8978-9666.

AndreevAtanas - Ph.D. in Medicine, doctor at the Department of Orthopedics and Traumatology, University Multiprofile Hospital for Active Treatment "Santa Anna". 1 Dymytr Molov St., Sofia, Bulgaria. ORCID: 0000-0002-7957-6787.

\section{Сведения об авторах:}

Зазирный Игорь Михайлович - доктор медищиских наук, руководитель Центра ортопедии, травматологии и спортивной медицины клинической больнищы "Феофания" Государственного управления делами, ул. акад. Заболотного, 21, Киев, 03143, Украина. ORCID: 0000-0001-7890-1499.

Коструб Александр Алексеевич - доктор медиинских наук, профессор, заведующий отделом спортивной и балетной травмы Гу "Институт травматологии и ортопедии НАМН Украины", ул. Бульварно-Кудрявская, 27, Киев, 01601, Украина. ORCID: 0000-0001-7925-9362.

ШІмигельский Роберт - доктор медииинских наук, ортопед в Институте Мирай, ул. Вольская, 96, 01-126, Варшава, Польша. ORCID: 0000-0001-8978-966б.

Андреев Атанас - кандидат медщинских наук, врач клиники ортопедии и травматологии, Университетская многопрофильная больница активного лечения "Святой Анны", ул. Димитр Молов, 1, София, Болгария. ORCID: 0000-0002-7957-6787.

Для кореспонденції: Зазірний Ігор Михайлович, керівник Центру ортопедії, травматології і спортивної медицини клінічної лікарні "Феофанія" Державного управління справами, вул. Дашавська, 25, кв. 14, 03056, Київ, Україна. Тел. +38(067)756-32-47. Факс: +38(044)259-67-68. E-mail: zazirny@ukr.net.

For correspondence: Zazirnyi Ihor Mykhailovych, head of the Center of Orthopedics, Traumatology and Sports Medicine of Clinical Hospital "Feofaniya" of the Agency of State Affairs, Apt. 14, 25 Dashavska St., 03056, Kyiv, Ukraine. Tel. +38(067)756-32-47. Fax. +38(044)259-67-68. E-mail: zazirny@ukr.net.

Для корреспонденции: Зазирный Игорь Михайлович, руководитель Центра ортопедии, травматологии и спортивной медицины клинической больницы "Феофания" Государственного управления делами, ул. Дашавская, 25, кв. 14, 03056, Киев, Украина. Тел. +38(067)756-32-47. Факс: +38(044)259-67-68. E-mail: zazirny@ukr.net. 